Zeszyty Naukowe Szkoły Głównej Gospodarstwa Wiejskiego w Warszawie

Problemy Rolnictwa Światowego tom 18 (XXXIII), zeszyt 1, 2018: 214-223

DOI: $10.22630 /$ PRS.2018.18.1.20

Ewa Rosiak

Instytut Ekonomiki Rolnictwa i Gospodarki Żywnościowej - Państwowy

Instytut Badawczy

\title{
Światowy rynek nasion oleistych i produktów ich przerobu
}

\section{The Global Market for Oilseeds and Their Processing Products}

\begin{abstract}
Synopsis. W artykule przedstawiono zmiany jakie nastąpiły w światowej produkcji, zużyciu i handlu nasionami oleistymi i produktami ich przerobu w XXI wieku. Analizę zmian przeprowadzono dla sześciu głównych regionów świata (Afryka, Azja, Ameryka Północna, Ameryka Południowa, Europa i Oceania) w oparciu o dane Organizacji Narodów Zjednoczonych do spraw Wyżywienia i Rolnictwa (FAOSTAT), które zagregowano do średnich z lat 2001-2004, 2005-2007, 2008-2010 i 2011-2013. W XXI wieku światowa produkcja i zużycie nasion oleistych, olejów roślinnych i śrut oleistych dynamicznie wzrasta, w następstwie rosnącego w skali globalnej popytu na żywność i energię odnawialną, przy czym w układzie regionalnym tempo wzrostu jest zróżnicowane. Rosną też obroty międzynarodowe tymi produktami, ale kierunki geograficzne handlu nie zmieniają się istotnie ze względu na brak znaczących zmian w samowystarczalności w zakresie nasion oleistych i produktów ich przerobu w poszczególnych regionach świata.
\end{abstract}

Słowa kluczowe: nasiona oleiste, oleje roślinne, śruty oleiste, produkcja, zużycie, handel

\begin{abstract}
The article presents changes that have occurred in the global production, consumption and trade of oilseeds and their processing products in the 21 st century. The analysis of changes was carried out for the six main regions of the world (Africa, Asia, North America, South America, Europe and Oceania) based on the data of the Food and Agriculture Organization of the United Nations (EUROSTAT), which were aggregated to the average from 2001-2004, 2005-2007, 2008-2010 and 2011-2013. In the 21st century, the global production and consumption of oilseeds, vegetable oils and oil pellets is growing dynamically in the wake of the growing global demand for food and renewable energy, while the regional growth rate is diversified. The international turnover of these products is also growing, but the geographical directions of trade do not change significantly due to the lack of significant changes in self-sufficiency in the field of oilseeds and their processing products in derivatives regions of the world.
\end{abstract}

Key words: oilseeds, vegetable oils, oilmeals, production, consumption, trade

JEL Classification: Q13

\section{Wprowadzenie}

Do najważniejszych roślin oleistych uprawianych na świecie zalicza się soję, rzepak, bawełnę, słonecznik, orzeszki ziemne, sezam, len i rącznik, będące przedmiotem jednorocznych upraw polowych oraz drzewa, takie jak: palma oleista, palma kokosowa i oliwka rosnące na plantacjach wieloletnich. Wymienione rośliny oleiste odgrywają bardzo ważną rolę $\mathrm{w}$ światowym rolnictwie, gospodarce żywnościowej i przemysłach

\footnotetext{
${ }^{1}$ dr inż., Zakład Badań Rynkowych IERiGŻ - PIB, ul. Świętokrzyska 20, 00-002 Warszawa, e-mail: rosiak@ierigz.waw.pl
} 
przetwórczych. Są one surowcem do produkcji tłuszczów konsumpcyjnych i technicznych. Stanowią źródło białka spożywczego i paszowego. Niektóre roślinny oleiste, jak bawełna i len, dostarczają też włókno roślinne (Bodył, Łopaciuk, Rosiak, Szajner, 2015).

W światowej produkcji i zużyciu, a zwłaszcza w handlu nasionami oleistymi dominuje soja (wg danych FAOSTAT w latach 2011-2013 stanowiła średnio 50\% w produkcji nasion ośmiu głównych roślin oleistych i $75 \% \mathrm{w}$ ich eksporcie) (tab. 1). W dalszej kolejności znajdują się: rzepak (odpowiednio 13\% i 15\%), orzechy kokosowe łącznie z koprą (11\% i $2 \%)$, bawełna ( $9 \%$ i $1 \%)$, nasiona słonecznika ( $8 \%$ i $4 \%)$, orzeszki ziemne $(6 \%$ i $2 \%)$, ziarna palmowe (3\% i poniżej $1 \%$ ) i sezam ( $1 \%$ i $1 \%)$. Uprawy roślin oleistych charakteryzują się znaczną koncentracją, szczególnie w przypadku soi, rzepaku oraz palmy oleistej. Ponad 80\% światowej produkcji soi uzyskuje się w USA, Brazylii i Argentynie, a prawie $90 \%$ światowej produkcji rzepaku w Unii Europejskiej, Kandzie, Chinach, Indiach i Australii. Plantacje palmy oleistej w około 90\% skoncentrowane są w Malezji i Indonezji.

Mimo dominującej pozycji soi na rynku nasion oleistych, na globalnym rynku olejów roślinnych od 2006 r. kluczową pozycję zajmuje olej palmowy (34\% udziału w produkcji ośmiu głównych olejów roślinnych średnio w latach 2011-2013 i 59\% udziału w ich eksporcie), a następnie sojowy ( $28 \%$ i $13 \%$ ), rzepakowy (16\% i $9 \%$ ) i słonecznikowy ( $9 \%$ i 11\%); natomiast na rynku śrut oleistych największy udział ma śruta sojowa (68\% udziału w produkcji ośmiu głównych śrut oleistych średnio w latach 2011-2013 i 71\% udziału w ich eksporcie) i w dalszej kolejności rzepakowa (13\% i 11\%).

Tabela 1. Struktura światowej produkcji, zużycia i handlu nasionami oleistymi i produktami ich przerobu

Table 1. The structure of global production, consumption and trade in oilseeds and their processing products

\begin{tabular}{|c|c|c|c|c|c|c|}
\hline \multirow{3}{*}{ Wyszczególnienie } & \multicolumn{6}{|c|}{ Średnia z lat: } \\
\hline & 2001-2004 & 2011-2013 & 2001-2004 & $2011-2013$ & 2001-2004 & 2011-2013 \\
\hline & \multicolumn{2}{|c|}{ Produkcja } & \multicolumn{2}{|c|}{ Zużycie } & \multicolumn{2}{|c|}{ Eksport } \\
\hline Nasiona oleiste $^{\mathrm{a}}$ & $100 \%$ & $100 \%$ & $100 \%$ & $100 \%$ & $100 \%$ & $100 \%$ \\
\hline w tym: soja & $50 \%$ & $50 \%$ & $50 \%$ & $50 \%$ & $77 \%$ & $75 \%$ \\
\hline rzepak & $10 \%$ & $13 \%$ & $11 \%$ & $13 \%$ & $11 \%$ & $15 \%$ \\
\hline Oleje roślinne ${ }^{b}$ & $100 \%$ & $100 \%$ & $100 \%$ & $100 \%$ & $100 \%$ & $100 \%$ \\
\hline w tym: palmowy & $28 \%$ & $34 \%$ & $27 \%$ & $32 \%$ & $53 \%$ & $59 \%$ \\
\hline sojowy & $31 \%$ & $28 \%$ & $32 \%$ & $29 \%$ & $22 \%$ & $13 \%$ \\
\hline rzepakowy & $14 \%$ & $16 \%$ & $14 \%$ & $16 \%$ & $7 \%$ & $9 \%$ \\
\hline Śruty oleiste ${ }^{c}$ & $100 \%$ & $100 \%$ & $100 \%$ & $100 \%$ & $100 \%$ & $100 \%$ \\
\hline w tym: sojowa & $69 \%$ & $68 \%$ & $69 \%$ & $69 \%$ & $79 \%$ & $71 \%$ \\
\hline rzepakowa & $11 \%$ & $13 \%$ & $11 \%$ & $12 \%$ & $7 \%$ & $11 \%$ \\
\hline
\end{tabular}

a - soja, rzepak, słonecznik, bawełna, orzeszki ziemne, sezam, ziarna palmowe, kopra

b - palmowy, sojowy, słonecznikowy, rzepakowy, z ziaren palmowych, kokosowy, arachidowy, bawełniany.

c - sojowa, rzepakowa, słonecznikowa, bawełniana, sezamowa, arachidowa, z ziaren palmowych, kokosowa.

Źródło: (FAOSTAT, Food balance, Food Balance Sheet, Commodity Balances - Crops Primary Equivalent;

Trade, Crops and livestock products, 2018), obliczenia własne. 


\section{Cel i metody badań}

Celem badań była analiza i ocena zmian jakie nastąpiły na światowym rynku nasion oleistych i produktów ich przerobu (olejów roślinnych i śrut oleistych) w XXI wieku. Analizę przeprowadzono dla sześciu głównych regionów świata (Afryka, Azja, Ameryka Północna, Ameryka Południowa, Europa i Oceania) w oparciu o dane Organizacji Narodów Zjednoczonych do spraw Wyżywienia i Rolnictwa (FAOSTAT), które zagregowano do średnich z lat 2001-2004, 2005-2007, 2008-2010 i 2011-2013. Do identyfikacji najważniejszych tendencji zachodzących w światowej produkcji, zużyciu i handlu nasionami oleistymi i produktami ich przerobu zastosowano podstawowe miary statystyki opisowej (wskaźniki struktury i dynamiki), a ocenę tych zmian przeprowadzono w oparciu o następujące mierniki:

- wskaźnik samowystarczalności (jest relacją produkcji do zużycia wewnętrznego, a jego wartość powyżej 100 informuje, że w regionie występują nadwyżki podaży lub dobra produkowane są z przeznaczeniem na eksport),

- saldo wymiany handlowej (obrazuje, czy w danej grupie produktów region jest eksporterem, czy importem netto),

- wskaźnik pokrycia importu eksportem TC (obrazuje w ujęciu względnym, w jakim stopniu wpływy z eksportu danej grupy produktów pokrywają wydatki na ich import) (Kapusta, 2012).

\section{Produkcja i zużycie}

Światowa produkcja nasion oleistych wykazuje wieloletni trend wzrostowy. W XXI wieku zwiększyła się z 378 mln ton średnio w latach 2001-20004 o do 524 mln ton średnio w latach 2011-2013, tj. o 39\% ${ }^{2}$. Zwiększenie produkcji nasion oleistych nastapiło we wszystkich regionach świata, przy czym największy, prawie dwukrotny wzrost miał miejsce w Europie i Oceanii (tab. 2). W Ameryce Południowej zbiory wzrosły o 57\%, w Afryce o 33\%, w Azji o 26\%, a w Ameryce Północnej o 22\%. Mimo relatywnie niewielkiego wzrostu, Azja nadal zajmuje kluczową pozycję w światowej produkcji nasion oleistych, choć jej udział obniżył się (z 37\% średnio w latach 2001-2004 do 34\% średnio w latach 2011-2013), a kolejne miejsca przypadają Ameryce Południowej (wzrost udziału z 25\% do 28\%), Ameryce Północnej (spadek udziału z 25\% do 22\%), Europie (wzrost udziału z $8 \%$ do $11 \%$ ), Afryce i Oceanii (stabilizacja udziału na poziomie odpowiednio 4\% i 1\%). Jednakże produkcja nasion oleistych w przeliczeniu na 1 mieszkańca najwyższa jest w krajach Ameryki (38,8 kg w Ameryce Południowej, 34,3 kg w Ameryce Północnej 2013 r.) i Oceanii (24,2 kg), a najniższa w krajach Afryki (2,1 kg) i Azji (4,2 kg). Niska jest też w krajach Europy $(8,6 \mathrm{~kg})$.

Podobnie jak produkcja, tak i przetwórstwo nasion oleistych i w ślad za tym produkcja olejów roślinnych dynamicznie wzrasta we wszystkich regionach świata, w tym najszybciej zwiększa się w krajach Azji (w Indonezji, Malezji i Chinach), Europy i Oceanii (tab. 3). $\mathrm{W}$ analizowanych latach światowa produkcja olejów roślinnych zwiększyła się z $95 \mathrm{mln}$ t.

\footnotetext{
${ }^{2}$ Dotyczy nasion: soi, rzepaku, słonecznika, bawełny, orzeszków ziemnych, sezamu, ziaren palmowych i kopry.
} 
średnio w latach 2001-2004 do $151 \mathrm{mln}$ ton średnio w latach 2011-2013, tj. o 59\% ${ }^{3}$. W Azji ich produkcja zwiększyła się o 66\%, w Europie i Oceanii po 64\%, w Ameryce Południowej o 45\%, w Ameryce Północnej o 45\%, a w Afryce o 17\%. Kraje Azji są zarówno największym producentem nasion oleistych, jak i olejów roślinnych na świecie (wzrost udziału w globalnej produkcji olejów z 55\% średnio w latach 2001-2004 do 57\% średnio w latach 2011-2013), a kolejne miejsca zajmują: kraje Europy (stabilizacja udziału na poziomie 14\%), Ameryki Południowej (spadek udziału z 13\% do 12\%), Ameryki Północnej (spadek udziału z 11\% do 9\%), Afryki (spadek udziału z 5\% do 4\%) i Oceanii (udział poniżej 1\%). Produkcja olejów roślinnych w przeliczeniu na 1 mieszkańca, podobnie jak nasion oleistych, największa jest $\mathrm{w}$ krajach Ameryki (45,5 kg w Ameryce Południowej, 38,4 kg w Ameryce Północnej - 2013 r.), a następnie Europy (30,6 kg). Znacznie niższa jest w krajach Azji (21,3 kg) i Oceanii (20,1 kg), a najniższa w krajach Afryki (5,5 kg).

Tabela 2. Produkcja, zużycie i handel nasionami oleistymi ${ }^{\mathrm{a}} \mathrm{wg}$ regionów

Table 2. Production, consumption and trade of oilseeds ${ }^{\mathrm{a}}$ by regions

\begin{tabular}{|c|c|c|c|c|c|c|c|c|}
\hline \multirow[b]{2}{*}{ Wyszczególnienie } & \multicolumn{8}{|c|}{ Średnia $\mathrm{z}$ lat: } \\
\hline & $\begin{array}{l}2001- \\
2004\end{array}$ & $\begin{array}{l}2005- \\
2007\end{array}$ & $\begin{array}{c}2008- \\
2010\end{array}$ & $\begin{array}{l}2011- \\
2013\end{array}$ & $\begin{array}{l}2001- \\
2004\end{array}$ & $\begin{array}{l}2005- \\
2007\end{array}$ & $\begin{array}{l}2008- \\
2010\end{array}$ & $\begin{array}{c}2011- \\
2013\end{array}$ \\
\hline & \multicolumn{4}{|c|}{ Afryka } & \multicolumn{4}{|c|}{ Azja } \\
\hline Produkcja (mln ton) & 15,0 & 15,4 & 17,0 & 19,9 & 140,3 & 160,0 & 167,2 & 176,1 \\
\hline Zużycie (mln ton) & 15,5 & 16,7 & 18,1 & 20,8 & 174,1 & 206,7 & 228,0 & 254,6 \\
\hline Eksport (mln ton) & 0,8 & 1,0 & 1,1 & 1,4 & 3,6 & 4,3 & 4,2 & 4,7 \\
\hline Import (mln ton) & 1,1 & 1,9 & 2,6 & 3,0 & 37,7 & 51,4 & 69,4 & 84,3 \\
\hline Saldo (mln ton) & $-0,3$ & $-0,9$ & $-1,5$ & $-1,6$ & $-34,1$ & $-47,1$ & $-65,2$ & $-79,6$ \\
\hline Wsk. samowystar. (\%) & 97 & 95 & 94 & 96 & 81 & 77 & 73 & 69 \\
\hline \multirow[t]{2}{*}{$\begin{array}{l}\text { Wsk. pokrycia importu } \\
\text { eksportem (TC) }{ }^{b}(\%)\end{array}$} & 78 & 82 & 79 & 83 & 9 & 8 & 6 & 6 \\
\hline & \multicolumn{4}{|c|}{ Ameryka Północna } & \multicolumn{4}{|c|}{ Ameryka Południowa } \\
\hline Produkcja (mln ton) & 94,7 & 103,9 & 112,4 & 115,2 & 92,3 & 114,6 & 125,7 & 145,3 \\
\hline Zużycie (mln ton) & 62,9 & 69,0 & 65,9 & 69,9 & 64,2 & 80,5 & 84,9 & 93,3 \\
\hline Eksport (mln ton) & 33,6 & 35,8 & 49,9 & 51,1 & 28,0 & 38,1 & 43,1 & 52,7 \\
\hline Import (mln ton) & 2,1 & 1,9 & 2,3 & 2,5 & 2,4 & 2,4 & 2,2 & 1,2 \\
\hline Saldo (mln ton) & 31,5 & 33,9 & 47,6 & 48,6 & 25,6 & 35,7 & 40,9 & 51,5 \\
\hline Wsk. samowystar. (\%) & 150 & 151 & 171 & 165 & 144 & 142 & 148 & 156 \\
\hline \multirow[t]{2}{*}{$\begin{array}{l}\text { Wsk. pokrycia importu } \\
\text { eksportem (TC) }{ }^{b}(\%)\end{array}$} & 1514 & 1707 & 2087 & 2008 & 1212 & 1441 & 1839 & 4248 \\
\hline & \multicolumn{4}{|c|}{ Europa } & \multicolumn{4}{|c|}{ Oceania } \\
\hline Produkcja (mln ton) & 29,9 & 39,7 & 48,9 & 57,8 & 3,4 & 3,2 & 3,8 & 6,5 \\
\hline Zużycie (mln ton) & 48,1 & 54,9 & 64,1 & 71,6 & 2,0 & 2,5 & 2,4 & 3,3 \\
\hline Eksport (mln ton) & 8,4 & 10,5 & 14,4 & 17,8 & 1,7 & 0,9 & 1,3 & 3,5 \\
\hline Import (mln ton) & 27,3 & 26,0 & 30,8 & 32,0 & 0,2 & 0,2 & 0,1 & 0,1 \\
\hline Saldo (mln ton) & $-18,9$ & $-15,5$ & $-16,4$ & $-14,2$ & 1,5 & 0,7 & 1,2 & 3,4 \\
\hline Wsk. samowystar. (\%) & 62 & 72 & 76 & 81 & 172 & 125 & 156 & 194 \\
\hline $\begin{array}{l}\text { Wsk. pokrycia importu } \\
\text { eksportem (TC) }{ }^{b}(\%)\end{array}$ & 31 & 40 & 44 & 52 & 1189 & 508 & 1149 & 3119 \\
\hline
\end{tabular}

${ }^{\mathrm{a}}$ - soja, rzepak, słonecznik, bawełna, orzeszki ziemne, sezam, ziarna palmowe, kopra; ${ }^{\mathrm{b}}$ - bez ziaren palmowych.

Źródło: FAOSTAT, Food balance, Food Balance Sheet; Trade, Crops and livestock products, 2018, obl. własne.

${ }^{3}$ Dotyczy olejów: palmowego, sojowego, słonecznikowego, rzepakowego, z ziaren palmowych, kokosowego, arachidowego i bawełnianego. 
Światowa produkcja śrut oleistych, które są produktem ubocznym powstającym przy produkcji olejów roślinnych, ale stanowią cenny, wysokobiałkowy surowiec paszowy, wzrosła ze $184 \mathrm{mln}$ ton średnio w latach 2001-2004 do $261 \mathrm{mln}$ ton średnio w latach 2011-2013, tj. o 42\% ${ }^{4}$. Znaczące zwiększenie produkcji śrut oleistych nastapiło we wszystkich regionach świata, z wyjątkiem Ameryki Północnej, gdzie ich produkcja wzrosła niewiele (tab. 4). Najbardziej wzrosła produkcja śrut oleistych w krajach Oceanii (o 83\%), następnie w krajach Azji (o 63\%), Afryki (o 52\%), Ameryki Południowej (o 44\%) i Europy (o 33\%), a najmniej w krajach Ameryki Północnej (o 9\%). Największym producentem śrut oleistych na świecie pozostają kraje Azji, a ponadto ich udział w globalnej produkcji śrut oleistych systematycznie wzrasta (z 36\% średnio w latach 2001-2004 do 42\% średnio w latach 2011-2013). Kolejne miejsca w światowej produkcji śrut oleistych zajmują: kraje Ameryki Południowej (spadek udziału z 26\% do 24\%), Ameryki Północnej (spadek udziału z 23\% do 17\%), Europy, Afryki i Oceanii (stabilizacja udziału na poziomie odpowiednio $14 \%, 3 \%$ i poniżej $1 \%$ ).

Od początku XXI wieku w ślad za rosnącą produkcją wzrasta światowe zużycie nasion oleistych i produktów ich przerobu. W skali globalnej rośnie bowiem popyt na żywność i energię odnawialną (Rosiak, 2014). Poprawa stanu wyżywienia społeczeństw, przy rosnącej liczbie ludności oraz rozwój produkcji biopaliw zwiększa popyt na oleje roślinne (Boczar, Sznajder, 2011). Jednocześnie rozwój produkcji zwierzęcej z zastosowaniem pasz przemysłowych, zwiększa popyt na wysokobiałkowe śruty oleiste. W ostatnich latach zapotrzebowanie na śruty oleiste wzrastało także z powodu kryzysu związanego z BSE i wprowadzenia w wielu krajach zakazu stosowania mączek mięsno-kostnych w żywieniu zwierząt gospodarskich.

W analizowanych latach światowe zużycie nasion oleistych (będące sumą produkcji importu i salda zapasów, pomniejszoną o eksport) zwiększyło się z $375 \mathrm{mln}$ ton średnio w latach 2001-2004 do $522 \mathrm{mln}$ ton średnio w latach 2011-2013, tj. o 39\% (w podobnej skali jak ich produkcja), olejów roślinnych z $92 \mathrm{mln}$ ton do $145 \mathrm{mln}$ ton, tj. o $58 \%$ (mniej niż ich produkcja), a śrut oleistych ze $183 \mathrm{mln}$ ton do $260 \mathrm{mln}$ ton, tj. o $42 \%$ (w podobnej skali jak ich produkcja). Zwiększenie zużycia nasion oleistych i produktów ich przerobu nastapiło we wszystkich regionach świata, przy czym zużycie nasion oleistych najbardziej wzrosło w krajach Oceanii (o 71\%) i Europy (o 49\%), olejów roślinnych w krajach Ameryki Południowej (prawie dwukrotnie) i Azji (o 67\%), a śrut oleistych w krajach Oceanii (trzykrotne) i Ameryki Południowej (dwukrotne). Najniższe wskaźniki wzrostu zużycia nasion oleistych, olejów roślinnych i śrut oleistych odnotowano w krajach Ameryki Północnej (odpowiednio 11\%, 26\% i 4\%) (tab. 2-4). Najwięcej nasion oleistych i produktów ich przerobu zużywają kraje Azji, które charakteryzują się najwyższymi wskaźnikami demograficznymi na świecie, a najmniej kraje Afryki ${ }^{5}$. Sytuacja pod tym względem w analizowanych latach nie zmieniła się. Kraje Azji mają 49\% (średnia z lat 2011-2013) udział w światowym zużyciu nasion oleistych, $53 \%$ udział w zużyciu olejów roślinnych i 46\% udział w zużyciu śrut oleistych. Udział krajów Afryki w światowym zużyciu olejów roślinnych jest $8 \%$, a w pozostałych grupach produktów oleistych $4 \%$. Kraje Afryki

\footnotetext{
${ }^{4}$ Dotyczy śrut: sojowej, rzepakowej, słonecznikowej, bawełnianej, sezamowej, arachidowej, z ziaren palmowych i kokosowej.

${ }^{5}$ Według danych FAOSTAT, w 2013 r. przy ogólnej liczbie ludności na świecie wynoszącej 7,0 mld, kraje Azji zamieszkiwało $61 \%$ ludności świata, kraje Afryki 14\%, Europy 11\%, Ameryki Południowej 6\%, Ameryki Północnej (bez Ameryki Środkowej i Karaibów) 5\%, Oceanii poniżej 1\%.
} 
charakteryzują się bowiem najniższym zużyciem produktów oleistych w przeliczeniu na 1 mieszkańca. Jednostkowe zużycie nasion oleistych w krajach Afryki (21 kg - 2013 r.), jest dziesięcio- jedenastokrotnie niższe niż w krajach Ameryki (200 kg w Ameryce Północnej, $228 \mathrm{~kg} \mathrm{w}$ Ameryce Południowej - 2013 r.), pięciokrotnie niższe niż w krajach Europy $(103 \mathrm{~kg})$ i Oceanii $(117 \mathrm{~kg})$ oraz trzykrotnie niższe niż w krajach Azji $(61 \mathrm{~kg})$. Jednostkowe zużycie olejów roślinnych w krajach Afryki $(12 \mathrm{~kg})$ jest trzykrotnie niższe w porównaniu z najwyższym ich zużyciem w krajach Ameryki $(39 \mathrm{~kg}$ w Ameryce Północnej, $31 \mathrm{~kg} \mathrm{w}$ Ameryce Południowej) i Europy ( $37 \mathrm{~kg}$ ), o połowę niższe niż w krajach Oceanii $(23 \mathrm{~kg})$ i o jedną trzecią niższe niż w krajach Azji (18 kg).

Tabela 3. Produkcja, zużycie i handel olejami roślinnymi ${ }^{\mathrm{a}}$ wg regionów

Table 3. Production, consumption and trade of vegetable oils ${ }^{\mathrm{a}}$ by regions

\begin{tabular}{|c|c|c|c|c|c|c|c|c|}
\hline \multirow[b]{2}{*}{ Wyszczególnienie } & \multicolumn{8}{|c|}{ Średnia z lat: } \\
\hline & $\begin{array}{l}2001- \\
2004\end{array}$ & $\begin{array}{l}2005- \\
2007\end{array}$ & $\begin{array}{c}2008- \\
2010\end{array}$ & $\begin{array}{l}2011- \\
2013\end{array}$ & $\begin{array}{l}2001- \\
2004\end{array}$ & $\begin{array}{l}2005- \\
2007\end{array}$ & $\begin{array}{l}2008- \\
2010\end{array}$ & $\begin{array}{c}2011- \\
2013\end{array}$ \\
\hline & \multicolumn{4}{|c|}{ Afryka } & \multicolumn{4}{|c|}{ Azja } \\
\hline Produkcja (mln ton) & 4,7 & 5,2 & 5,4 & 5,5 & 52,1 & 67,1 & 76,8 & 86,4 \\
\hline Zużycie (mln ton) & 8,3 & 10,2 & 11,1 & 11,4 & 46,2 & 59,2 & 65,8 & 77,2 \\
\hline Eksport (mln ton) & 0,5 & 0,7 & 1,1 & 1,2 & 25,2 & 33,9 & 41,6 & 46,1 \\
\hline Import (mln ton) & 4,0 & 5,9 & 7,1 & 7,4 & 19,8 & 26,0 & 30,5 & 35,7 \\
\hline Saldo (mln ton) & $-3,5$ & $-5,2$ & $-6,0$ & $-6,2$ & 5,4 & 7,9 & 11,1 & 10,4 \\
\hline Wsk. samowystar. (\%) & 56 & 51 & 48 & 48 & 113 & 113 & 117 & 112 \\
\hline \multirow[t]{2}{*}{$\begin{array}{l}\text { Wsk. pokrycia importu } \\
\text { eksportem (TC) }{ }^{b}(\%)\end{array}$} & 12 & 12 & 13 & 14 & 92 & 106 & 113 & 100 \\
\hline & \multicolumn{4}{|c|}{ Ameryka Północna } & \multicolumn{4}{|c|}{ Ameryka Południowa } \\
\hline Produkcja (mln ton) & 10,6 & 12,2 & 12,1 & 13,3 & 12,8 & 16,0 & 17,1 & 18,6 \\
\hline Zużycie (mln ton) & 10,6 & 11,5 & 12,1 & 13,4 & 6,5 & 7,3 & 10,0 & 12,6 \\
\hline Eksport (mln ton) & 2,1 & 2,6 & 4,1 & 4,6 & 7,8 & 10,4 & 8,8 & 8,2 \\
\hline Import (mln ton) & 1,9 & 2,7 & 3,5 & 4,0 & 1,3 & 1,6 & 1,9 & 2,3 \\
\hline Saldo (mln ton) & 0,2 & $-0,1$ & 0,6 & 0,6 & 6,5 & 8,8 & 6,9 & 5,9 \\
\hline Wsk. samowystar. (\%) & 99 & 107 & 100 & 99 & 204 & 221 & 171 & 147 \\
\hline \multirow[t]{2}{*}{$\begin{array}{l}\text { Wsk. pokrycia importu } \\
\text { eksportem (TC) }{ }^{\mathrm{b}}(\%)\end{array}$} & 143 & 117 & 128 & 123 & 543 & 588 & 432 & 361 \\
\hline & \multicolumn{4}{|c|}{ Europa } & \multicolumn{4}{|c|}{ Oceania } \\
\hline Produkcja (mln ton) & 13,1 & 16,3 & 19,4 & 21,4 & 0,3 & 0,4 & 0,4 & 0,5 \\
\hline Zużycie (mln ton) & 17,6 & 22,6 & 25,7 & 26,6 & 0,5 & 0,6 & 0,6 & 0,7 \\
\hline Eksport (mln ton) & 9,1 & 12,2 & 14,5 & 17,2 & 0,2 & 0,2 & 0,2 & 0,2 \\
\hline Import (mln ton) & 13,8 & 18,9 & 21,1 & 21,4 & 0,3 & 0,4 & 0,4 & 0,4 \\
\hline Saldo (mln ton) & $-4,7$ & $-6,7$ & $-6,6$ & $-4,2$ & $-0,1$ & $-0,2$ & $-0,2$ & $-0,2$ \\
\hline Wsk. samowystar. (\%) & 74 & 72 & 75 & 81 & 67 & 65 & 68 & 78 \\
\hline $\begin{array}{l}\text { Wsk. pokrycia importu } \\
\text { eksportem (TC) }{ }^{\mathrm{b}}(\%)\end{array}$ & 70 & 67 & 70 & 86 & 124 & 104 & 135 & 162 \\
\hline
\end{tabular}

a - palmowy, sojowy, słonecznikowy, rzepakowy, z ziaren palmowych, kokosowy, arachidowy, bawełniany.

Źródło: FAOSTAT, Food balance, Food Balance Sheet; Trade, Crops and livestock products, 2018, obliczenia własne. 


\section{Samowystarczalność}

Samowystarczalność w zakresie nasion oleistych i produktów ich przerobu jest bardzo zróżnicowana $\mathrm{w}$ poszczególnych regionach świata $\mathrm{i}$ sytuacja pod tym względem w analizowanych latach nie zmieniła się znacząco, na co wskazują wskaźniki samowystarczalności, które są relacją produkcji do zużycia (liczonego jako suma produkcji importu i salda zapasów, pomniejszona o eksport) (tab. 2-4).

Tabela 4. Produkcja, zużycie i handel śrutami oleistymi ${ }^{\mathrm{a}}$ wg regionów

Table 4. Production, consumption and trade of oilmeals a by regions

\begin{tabular}{|c|c|c|c|c|c|c|c|c|}
\hline \multirow[b]{2}{*}{ Wyszczególnienie } & \multicolumn{8}{|c|}{ Średnia $\mathrm{z}$ lat: } \\
\hline & $\begin{array}{l}2001- \\
2004\end{array}$ & $\begin{array}{l}2005- \\
2007\end{array}$ & $\begin{array}{l}2008- \\
2010\end{array}$ & $\begin{array}{l}2011- \\
2013\end{array}$ & $\begin{array}{l}2001- \\
2004\end{array}$ & $\begin{array}{l}2005- \\
2007\end{array}$ & $\begin{array}{l}2008- \\
2010\end{array}$ & $\begin{array}{c}2011- \\
2013\end{array}$ \\
\hline & \multicolumn{4}{|c|}{ Afryka } & \multicolumn{4}{|c|}{ Azja } \\
\hline Produkcja (mln ton) & 4,7 & 5,3 & 6,1 & 7,2 & 66,7 & 83,3 & 93,9 & 108,4 \\
\hline Zużycie (w mln ton) & 7,0 & 7,6 & 8,7 & 11,3 & 72,3 & 89,9 & 102,9 & 120,4 \\
\hline Eksport (mln ton) & 0,4 & 0,3 & 0,4 & 0,5 & 7,6 & 12,0 & 12,6 & 14,7 \\
\hline Import (mln ton) & 2,7 & 2,6 & 3,0 & 4,7 & 13,8 & 18,3 & 21,7 & 26,9 \\
\hline Saldo (mln ton) & $-2,3$ & $-2,3$ & $-2,6$ & $-4,2$ & $-6,2$ & $-6,3$ & $-9,1$ & $-12,2$ \\
\hline Wsk. samowystar. (\%) & 68 & 70 & 70 & 64 & 92 & 93 & 91 & 90 \\
\hline \multirow[t]{2}{*}{$\begin{array}{l}\text { Wsk. pokrycia importu } \\
\text { eksportem (TC) }{ }^{\mathrm{b}}(\%)\end{array}$} & 9 & 6 & 6 & 7 & 31 & 43 & 37 & 36 \\
\hline & \multicolumn{4}{|c|}{ Ameryka Północna } & \multicolumn{4}{|c|}{ Ameryka Południowa } \\
\hline Produkcja (mln ton) & 40,2 & 43,7 & 41,7 & 44,0 & 43,3 & 54,5 & 56,9 & 62,2 \\
\hline Zużycie (w mln ton) & 35,8 & 39,1 & 34,7 & 37,3 & 13,0 & 19,0 & 22,2 & 26,0 \\
\hline Eksport (mln ton) & 6,7 & 7,6 & 9,8 & 10,6 & 32,8 & 39,7 & 38,9 & 41,0 \\
\hline Import (mln ton) & 2,3 & 2,9 & 2,8 & 3,9 & 2,6 & 4,1 & 4,2 & 4,7 \\
\hline Saldo (mln ton) & 4,4 & 4,7 & 7,0 & 6,7 & 30,2 & 35,6 & 34,7 & 36,3 \\
\hline Wsk. samowystar. (\%) & 112 & 112 & 120 & 118 & 332 & 286 & 257 & 240 \\
\hline \multirow[t]{2}{*}{$\begin{array}{l}\text { Wsk. pokrycia importu } \\
\text { eksportem (TC) }{ }^{b}(\%)\end{array}$} & 324 & 322 & 449 & 327 & 940 & 730 & 744 & 758 \\
\hline & \multicolumn{4}{|c|}{ Europa } & \multicolumn{4}{|c|}{ Oceania } \\
\hline Produkcja (mln ton) & 25,9 & 28,7 & 32,4 & 34,5 & 0,6 & 0,7 & 0,6 & 1,0 \\
\hline Zużycie (w mln ton) & 49,6 & 53,4 & 55,0 & 55,4 & 1,0 & 1,6 & 2,4 & 3,1 \\
\hline Eksport (mln ton) & 11,5 & 15,6 & 18,3 & 20,5 & 0,0 & 0,0 & 0,0 & 0,1 \\
\hline Import (mln ton) & 35,3 & 40,4 & 41,4 & 41,2 & 0,5 & 0,9 & 1,8 & 2,1 \\
\hline Saldo (mln ton) & $-23,8$ & $-24,8$ & $-23,1$ & $-20,7$ & $-0,5$ & $-0,9$ & $-1,8$ & $-2,0$ \\
\hline Wsk. samowystar. (\%) & 52 & 54 & 59 & 62 & 56 & 43 & 27 & 33 \\
\hline $\begin{array}{l}\text { Wsk. pokrycia importu } \\
\text { eksportem (TC) }{ }^{\mathrm{b}}(\%)\end{array}$ & 31 & 34 & 37 & 43 & 4 & 1 & 3 & 5 \\
\hline
\end{tabular}


Na podstawie wskaźników samowystarczalności można wnioskować, iż mimo rozwoju produkcji nasion oleistych we wszystkich regionach świata, największe niedobory nasion oleistych w relacji do zużycia utrzymują się w krajach Azji i Europy, niewielkie w krajach Afryki, a ich nadprodukcja stale występuje w krajach Ameryki Północnej i Południowej oraz Oceanii. W analizowanych latach sytuacja pod tym względem nie zmieniła się znacząco, przy czym samowystarczalność krajów Europy w zakresie nasion oleistych wzrosła (z 62\% średnio w latach 2001-2004 do 81\% średnio w latach 2011-2013), a krajów Azji obniżyła się (odpowiednio z 81\% do 69\%). Znacząco wzrosła nadprodukcja i wskaźniki samowystarczalności w zakresie nasion oleistych krajów Ameryki Północnej (ze $150 \%$ do 165\%) i Południowej (ze 144\% do 156\%) oraz Oceanii (ze 172\% do 194\%). Samowystarczalność w zakresie nasion oleistych w krajach Afryki zmieniła się w niewielkim zakresie (zmniejszyła się z 97\% do 96\%).

W zakresie olejów roślinnych największe i pogłębiające się niedobory produkcji w relacji do zużycia występują w krajach Afryki (spadek samowystarczalności z 56\% średnio w latach 2001-2004 do 48\% średnio w latach 2011-2013). Mimo poprawy, niską samowystarczalność w zakresie olejów roślinnych mają też kraje Europy (74\% średnio w latach 2001-2004 i 81\% średnio w latach 2011-2013) i Oceanii (odpowiednio 67\% i 78\%). Najwyższą, ale malejącą nadprodukcją i samowystarczalnością w zakresie olejów roślinnych charakteryzują się kraje Ameryki Południowej (w analizowanych latach spadek samowystarczalności z 204\% do 147\%). Wysoka samowystarczalność w zakresie olejów roślinnych wstępuje też w krajach Azji (odpowiednio 113\% i 112\%) i Ameryki Północnej (stabilizacja na poziomie 99\%).

W zakresie śrut oleistych w większości regionów świata występują duże niedobory produkcji względem potrzeb i w analizowanych latach sytuacja pod tym względem nie zmieniła się znacząco. Duże niedobory produkcji i niska samowystarczalność w zakresie śrut oleistych utrzymuje się w krajach Europy (52\% średnio w latach 2001-2004 i 62\% średnio w latach 2011-2013), Afryki (odpowiednio 68\% i 64\%), Oceanii (56\% i 33\%) i Azji (92\% i 90\%), a ich duże nadwyżki i wysoka samowystarczalność stale występuje tylko w krajach Ameryki Południowej (w analizowanych latach spadek z 332\% do 240\%) i Północnej (odpowiednio 112\% i 118\%).

\section{Handel}

Dynamicznie rosnący popyt na oleje roślinne sektora spożywczego i przemysłowego oraz na białko roślinne sektora paszowego spowodował w XXI wieku bardzo znaczący wzrost obrotów międzynarodowych nasionami oleistymi i produktami ich przerobu, przy czym kierunki geograficzne handlu nie zmieniły się istotnie w porównaniu z wcześniejszymi latami (Rutkowski, 1978, Gawron, Burakiewicz, Zapędowski, 1995), ze względu na brak znaczonych zmian w samowystarczalności w zakresie tej grupy produktów w poszczególnych regionach świata.

Światowy eksport nasion oleistych zwiększył się o 73\% (z 76 mln ton średnio w latach 2001-2004 do $131 \mathrm{mln}$ ton w średnio w latach 2011-2013), olejów roślinnych o 80\% (odpowiednio z $45 \mathrm{mln}$ ton do $81 \mathrm{mln}$ ton), a śrut oleistych o $48 \%$ (z $59 \mathrm{mln}$ ton do $87 \mathrm{mln}$ ton). Eksport w stosunku do produkcji dla nasion oleistych wzrósł w porównywanych okresach z $20 \%$ do $25 \%$, dla olejów roślinnych z $48 \%$ do $54 \%$, a dla śrut oleistych z $30 \%$ do $34 \%$. Znaczące zwiększenie obrotów handlowych nasionami oleistych i produktami ich 
przerobu nastąpiło we wszystkich regionach świata (tab. 2-4). Wyjątkiem było tylko zmniejszenie przywozu nasion oleistych przez kraje Ameryki Południowej (o połowę w porównywanych okresach) i kraje Oceanii (o jedna piąta). Eksport nasion oleistych najbardziej zwiększyły kraje Europy (ponad dwukrotnie), olejów roślinnych kraje Afryki (prawie trzykrotnie), a śrut oleistych kraje Oceanii (ponad trzykrotnie), natomiast import nasion oleistych najbardziej wzrósł do krajów Afryki (prawie trzykrotnie), olejów roślinnych do krajów Ameryki Północnej (ponad dwukrotnie), a śrut oleistych do krajów Oceanii (trzyipółkrotnie).

Mimo dynamicznego rozwoju produkcji i przetwórstwa nasion oleistych we wszystkich regionach świata, regionami deficytowymi $\mathrm{w}$ nasiona oleiste i produkty ich przerobu i w związku z tym kluczowymi ich importerami netto pozostały kraje Azji ${ }^{6}$ (65\% udziału w globalnym imporcie nasion oleistych, 34\% udziału w imporcie olejów roślinnych i 31\% udziału w imporcie śrut oleistych średnio w latach 2011-2013) i Europy (odpowiednio 25\%, 28\% i 48\%), natomiast regionami nadwyżkowymi i największymi eksporterami netto nasion oleistych nadal były kraje Ameryki Północnej i Południowej (odpowiednio 39\% i 40\% udziału w globalnym eksporcie nasion oleistych), śrut oleistych kraje Ameryki Południowej (47\% udziału), a olejów roślinnych kraje Azji (57\% udziału), w tym głównie Azji Południowo-Wschodniej. Importerami netto nasion oleistych i produktów ich przerobu były też kraje Afryki i Oceanii (nie dotyczy nasion oleistych).

W analizowanych latach w krajach Azji i Afryki pogłębiało się ujemne saldo handlu zagranicznego nasionami i śrutami oleistymi, a wskaźniki pokrycia importu eksportem (TC) (ang. Trade Coverage) były niskie i nie wykazywały większych zmian. W krajach Afryki pogłębiło się też ujemne saldo handlu olejami roślinnymi, a w krajach Oceanii olejami roślinnymi i śrutami oleistymi. Zmniejszenie ujemnego salda i wzrost wskaźników TC odnotowano tylko w krajach Europy (dla nasion oleistych z 31\% średnio w latach 2001-2004 do 52\% w średnio w latach 2011-2013, dla olejów roślinnych z 70\% do 86\%, a dla śrut oleistych z 31\% do 43\%). W krajach Ameryki, w tym szczególnie Ameryki Południowej, dynamicznie wzrastało dodatnie saldo handlu nasionami oleistymi i produktami ich przerobu, a wskaźniki pokrycia importu eksportem były bardzo wysokie. W zakresie olejów roślinnych znaczący wzrost dodatniego salda obrotów handlowych i wskaźników TC nastąpił też w krajach Azji.

\section{Podsumowanie}

W XXI wieku światowa produkcja i zużycie nasion oleistych i produktów ich przerobu (olejów roślinnych i śrut oleistych) dynamicznie wzrasta, w następstwie rosnącego w skali globalnej popytu na żywność i energię odnawialną, przy czym w układzie regionalnym tempo wzrostu jest zróżnicowane. Produkcja nasion oleistych najszybciej wzrasta w krajach Europy i Oceanii, a ich przetwórstwo i w ślad za tym produkcja olejów roślinnych i śrut oleistych w krajach Azji, Europy i Oceanii. Kraje Azji pozostają największym producentem i konsumentem nasion oleistych i produktów ich przerobu na świecie, ale jednostkowa ich produkcja i konsumpcja w krajach Azji jest niska. Najwyższa jest w krajach Ameryki Północnej i Południowej. Najniższy udział w globalnej produkcji i zużyciu nasion oleistych i produktów ich przerobu mają kraje Oceanii i Afryki.

${ }^{6} \mathrm{Z}$ wyjątkiem olejów roślinnych. Kraje Azji były największym światowym importerem i eksporterem olejów roślinnych, ale saldo obrotów tymi produktami miały dodatnie. 
Kraje Afryki charakteryzują się też najniższą na świecie produkcją i zużyciem nasion oleistych i produktów ich przerobu w przeliczeniu na 1 mieszkańca i sytuacja pod tym względem w analizowanych latach nie zmieniła się.

Dynamicznie rosnący popyt na oleje roślinne sektora spożywczego i przemysłowego oraz na białko roślinne sektora paszowego spowodował w XXI wieku bardzo znaczący wzrost obrotów międzynarodowych nasionami oleistymi i produktami ich przerobu. Jednakże kierunki geograficzne handlu nie zmieniły się istotnie $\mathrm{w}$ porównaniu z wcześniejszymi latami, ze względu na brak znaczonych zmian w samowystarczalności w zakresie tej grupy produktów w poszczególnych regionach świata. Regionami deficytowymi w surowce i produkty oleiste $\mathrm{i}$ w związku $\mathrm{z}$ tym największymi ich importerami pozostają kraje Azji (przede wszystkim Chiny i Indie), Europa i Afryka, a regionami nadwyżkowymi i kluczowymi eksporterami kraje Ameryki Północnej (USA, Kanada) i Południowej (Brazylia, Argentyna), a także kraje Azji Południowo-Wschodniej (Malezja i Indonezja) i Oceanii (Australia).

\section{Literatura}

Boczar, P., Sznajder, M. (2011). Rozwój światowego rynku olejów roślinnych w latach 1961-2005 (The development of the global market for vegetable oils in 1961-2005), UP w Poznaniu.

Bodył, M., Łopaciuk, W., Rosiak, E., Szajner, P. (2015). Sytuacja na światowym rynku zbóż, roślin oleistych, cukru, biopaliw oraz jej wpływ na krajowe rynki produktów roślinnych i możliwości ich rozwoju (The situation on the global cereal, oilseed, sugar and biofuels market and its impact on domestic markets of plant products and the possibilities of their development), seria „Monografie Programu Wieloletniego”, nr 1, IERiGŻ-PIB, Warszawa.

Gawron, W., Burakiewicz, J., Zapędowski, W. (1995). Stan i perspektywy handlu zagranicznego oleistymi (The state and perspectives of foreign oil trade), IERiGŻ, Warszawa.

Kapusta, F. (2012). Agrobiznes (Agribusiness), Difin, Warszawa.

Rosiak, E. (2014). Światowy rynek biodiesla i surowców do jego produkcji (The world market for biodiesel and raw materials for its production). Rocznik Rośliny Oleiste - Oilseeds Crops, 35, 7-19.

Rutkowski, J. (1978). Tendencje rozwojowe w produkcji i obrotach międzynarodowych nasionami oleistymi i thuszczami pochodzenia roślinnego (Development trends in the production and international trade of oilseeds and vegetable fats), Rozprawa doktorska, SGGW, Warszawa.

Do cytowania / For citation:

Rosiak E. (2018). Światowy rynek nasion oleistych i produktów ich przerobu. Problemy Rolnictwa Światowego, 18(1), 214-223; DOI: 10.22630/PRS.2018.18.1.20

Rosiak E. (2018). The Global Market for Oilseeds and Their Processing Products (in Polish). Problems of World Agriculture, 18(1), 214-223; DOI: 10.22630/PRS.2018.18.1.20 